lawful area of self-help in labor disputes..$^{58}$ The question remains whether any such policy justifies pegging the right on the level of a constitutional privilege. If picketing is sufficiently important, pro-picketing legislation would seem the more desirable alternative. If the requisite political power is lacking, is it the office of the judiciary to remedy the deficiency? Surely the vigorous role assumed by the legislatures in the regulation of industrial conflict militates strongly against judicial intervention.

Should the rise of the unlawful-object test be welcomed as a qualification of an unsound doctrine? If unlawful objects are subject to clear-and-present-danger techniques, a substantial part of the Thornhill doctrine may yet be salvaged from the Giboney case. But the extensive pre-Giboney use of the unlawful-object test indicates that such restraint will not be exercised. Continued lip-service to the Thornhill doctrine seems an unpardonable subterfuge if the creation of unlawful objects is governed only by judicial and legislative whimsy. The Supreme Court has argued that the Giboney case does not qualify Thornhill v. Alabama. A generous interpretation of the decision may support this contention. The critical test will come when the Court decides whether a state may outlaw the closedshop picket or recruiting picket by employing the illegal purpose device. If such objects do not threaten a clear and present danger of substantive evil, the Supreme Court will have to elect between affirmation or repudiation of the Thornhill doctrine. ${ }^{99}$ The real problem must then be faced. Are the courts or the legislatures the proper organs of labor policy?

\title{
CHURCH AND SPIEGEL IN PERSPECTIVE
}

In two recent companion cases dealing with the federal estate tax, Com'r v. Estate of Church ${ }^{2}$ and Estate of Spiegel v. Com'r, ${ }^{2}$ the members of the Supreme Court wrote six opinions reflecting the provocative treatment of the subject they belabor. The opinions - two majority, three dissenting, and one dissenting in part-reached the impressive length of 55,000 words. These opinions were

${ }^{5}$ See Riesman, Civil Liberties in a Period of Transition, 3 Pub. Policy 80 (I942); Meiklejohn, Free Speech and Its Relation to Self Government 63 (1948); Holmes, J., in Vegelahn v. Gunter, I67 Mass. 92, I06, 44 N.E. I077, 1080 (I896): "The true grounds of decision are considerations of policy and of social advantage, and it is vain to suppose that solutions can be attained merely by logic and general propositions of law which nobody disputes. Propositions as to public policy rarely are unanimously accepted, and still more rarely, if ever, are capable of unanswerable proof."

59 The Supreme Court has already granted certiorari to review a case in which picketing to induce an employer to adopt a discriminatory hiring policy was enjoined. Hughes v. Superior Court, I5 C.C.H. Lab. Cas. $\lceil 64824$ (Calif., I948), cert. granted 69 S. Ct. 930 (I949). The impending Hughes case will be the acid test for the Thornhill doctrine. The Court's recent denial of certiorari in the less critical case of Pa. L.R.B. v. Chester and Delaware Counties Bartenders Local, $36 \mathrm{r}$ Pa. 246 (1949), cert. den. 69 S. Ct. 812 (I949), may indicate that the Hughes case was chosen specifically for this purpose.
${ }^{2} 335$ U.S. 632 (1949).
2335 U.S. 701 (1949). 
especially notable because the inauspicious beginning of the cases in the lower courts did not herald the expansive reception they were to receive in the Supreme Court. Not satisfied with the limited nature of the initial oral argument, the Court, envisioning a more significant role for these cases, stimulated counsel to prepare additional argument on nine questions it had propounded. 3 Fifteen months after the original hearing the long-awaited decisions were handed down.

The questions, because they related to the desirability of overruling several of the Court's established interpretations of Section $8 \mathrm{II}(\mathrm{c})$ of the Internal Revenue Code, ${ }^{4}$ raised doubts as to the present status of many of the Court's former holdings. ${ }^{5}$ When the Court announced its results, one major precedent of nineteen years' standing ${ }^{6}$ had been overruled. This was the second important interpretation of Section $8 I I$ (c) discarded by the Court in the past ten years. ${ }^{7}$ But the status of other holdings upon which doubt had been cast by the Court's nine questions was not explicitly resolved by the majority opinions.

The Church and Spiegel decisions immediately occasioned lengthy comments, criticisms, and proposals for legislative correction from members of the bar. ${ }^{8}$ At least one state legislature reacted by passing an act changing the state's property law in such a manner as to circumvent the Spiegel decision. ${ }^{9}$ The Spiegel decision appeared particularly irritating because the imposition of a tax of $\$ 45^{\circ}, 000$ turned on a highly technical point of the future interests law of Illinois.

\section{II}

The 55,000 words of the opinions were devoted to interpreting one phrase in Section $8 \mathrm{II}(\mathrm{c})$ of the estate tax provisions of the Internal Revenue Code. ${ }^{10}$ The

3 Journal S. Ct., Oct. Term 1947, 296-98; Estate of Spiegel v. Com'r, 68 S. Ct. I522 (1948); Com'r v. Estate of Church, 68 S. Ct. I524 (I948).

4 Revenue Act of $1926, \S 302$ (c), 44 Stat. 9, 70 (xg26), as amended by Revenue Act of 1932 , \$803(a), 47 Stat. 169, 279 (1932), 26 U.S.C.A. \$ 8 II(c) (1947).

5 The questions specifically related to the propriety of overruling Reinecke v. Northern Trust Co., 278 U.S. 339 (I929), and May v. Heiner, 28I U.S. 238 (I930).

${ }^{6}$ May v. Heiner, 281 U.S. 238 (1930).

7 In I940, Helvering v. Hallock, $3 \circ 9$ U.S. Io6, overruled the companion cases, Helvering v. St. Louis Union Trust Co., 296 U.S. 39 (1935), and Becker v. St. Louis Union Trust Co., 296 U.S. 48 (1935).

${ }^{8}$ See Conway, I.R.C. $\$ 8 \operatorname{II}(\mathrm{c})-$ The Church and Spiegel Interpretation, 34 Corn. L.Q. 376 (1949); Durbin, Estate Taxation of Inter-Vivos Trusts after Spiegel and Church, 30 Chicago Bar Record I99 (1949); Foosaner, New Estate Planning Hazard, 88 Trusts \& Estates ro8 (r949); Looker, Estate Taxation of Living Trusts: The Church and Spiegel Decisions, 49 Col. L. Rev. 437 (I949); Schrenk and Wellman, The Church and Spiegel Cases, 47 Mich. L. Rev. 655 (I949); Schuyler, address delivered at Chicago Bar Association section meeting (March 9, I949); The Church and Spiegel Cases: The Meaning of a Transfer Effective at Death, 49 Col. L. Rev. 533 (I949).

9 Minn. L. I949, c. 201 (approved March 26, 1949).

ro 47 Stat. I69, 279 (I932), 26 U.S.C.A. § 8 II (c) (I947). 
particular clause of this section construed in the Church and Spiegel cases brings into the donor's gross estate at his death certain interests he has transferred during his life. The interests brought back are considered to be like testamentary dispositions in that the donees must await full enjoyment of their interests until the donor's death. Section $8 \mathrm{xI}$ (c) provides that, "The value of the gross estate of the decedent shall be determined by including the value at the time of his death of all property.... (c) To the extent of any interest therein of which the decedent has at any time made a transfer by trust, or otherwise ... intended to take effect in possession or enjoyment at or after his death. ..." It was designed to prevent evasion of the estate tax. The application of the "possession or enjoyment" clause always involves a determination of what interests transferred by a donor during his life should be brought back into his gross estate at death. In the instant cases, the Supreme Court held, on the basis of the above statutory provision, that certain interests transferred by inter vivos trust should be included in the gross estates of the decedents Spiegel and Church.

Section $8 \mathrm{rr}$ (c) also requires gifts made "in contemplation of death" to be included in decedents' gross estates; however, the only aspect of this section involved in the Church and Spiegel cases was the "possession or enjoyment" clause. Future references in this note to Section $8 \operatorname{II}$ (c) will therefore apply only to the "possession or enjoyment" clause.

In I924 Francois Church executed an inter vivos trust instrument, reserving the income for his life. Upon his death, which occurred in 1939 , the trust was to terminate and the corpus was to be distributed among his children, or, if none were living, among his brothers and sisters. ${ }^{\text {II }}$ The Supreme Court held that the corpus of this inter vivos trust was to be brought back into the decedent's gross estate on the basis of Section $8 \mathrm{rI}$ (c), because the children's enjoyment of their interests was suspended until the termination of the donor's life interest.

In 1920 Sydney Spiegel executed a trust instrument providing that during his life the income was to be divided among his three children, or, in the event of their deaths, among their surviving children. Upon the donor's death, the corpus was to be distributed in a like manner. Although the donor apparently attempted to dispose of his entire interest in the trust property, the Court found

xx The settlor also retained a possibility of reverter arising by operation of law. The only point at issue in the lower courts and presented to the Supreme Court for consideration on appeal was whether this retention of a possibility of reverter required the inclusion of the corpus of the trust in the settlor's gross estate at his death. A similar point was at issue in the Spiegel case, and the Supreme Court consolidated the actions. Of its own motion, the Court requested argument on whether May v. Heiner, 28I U.S. 238 (I930), should be overruled, i.e., whether the reservation of the life estate by Mr. Church, regardless of the possibility of reverter, required the value of the corpus in the Church trust to be included in the decedent's gross estate. Since the Court held that the corpus must be included in the decedent's gross estate because the settlor retained a life estate, it was unnecessary for the Court to consider the possibility of reverter point in the Church case. 
that he failed to do so because the instrument made no provision for the distribution of the corpus in the event that all of the settlor's children and grandchildren predeceased him. The Court concluded that the property would have reverted to the settlor if such an unlikely event had occurred..$^{2}$ Because the donor inadvertently retained until his death the theoretical possibility of regaining the trust property, ${ }^{\mathrm{r} 3}$ the Court held that the entire corpus of the trust should be brought back into the donor's estate at death. The value of the settlor's reversionary interest was admittedly included in the donor's gross estate under Section $8 \operatorname{rr}(a)$ and was not at issue in this case. The certainty that the children would come into enjoyment of their interest in the corpus arose only at the settlor's death, when his possibility of regaining the property ended. Therefore, the Court viewed the trust transfer as within the terms of Section $8 \mathrm{rI}(\mathrm{c})$.

To the beneficiaries, the bitter reality of the Court's reasoning was an additional tax of $\$ 450,000$ imposed on the estate because the trust instrument had failed to specify an ultimate taker in the event a theoretically possible but highly improbable event had occurred-namely, the death of all the contingent beneficiaries before the death of the settlor. The actuarial value of the settlor's reversionary interest just prior to his death amounted to $\$ 70,{ }^{, 4}$ but the retention of this insignificant interest resulted in tax liability to the Spiegel estate of more than six thousand times the value of the interest.

The result at which the majority of the Court arrived in the Spiegel case is not easily foreseen from a mere perusal of the language of Section 8II(c). The evident underlying purpose of the section is to bring into the decedent's gross estate those interests he has transferred in an attempt to avoid the estate tax. Apparently, as was pointed out above, the settlor in the Spiegel case attempted to dispose of all his interest in the trust property and had no intention of avoiding the estate tax. On the other hand, the Church result is more nearly in accord with the purpose of Section $8 \operatorname{Ir}$ (c) because the settlor in that case, under his reserved life estate, continued to enjoy the benefits of the property until his death, at which time, the benefits passed to his children. And yet the Court's past construction of the "possession or enjoyment" clause has been such that, immediately prior to the announcement of the Court's decisions, persons familiar with the judicial history of Section $8 \mathrm{II}$ (c) could have more easily anticipated the result in the Spiegel case than the result in the Church case.

12 The Supreme Court accepted the finding of the Court of Appeals for the Seventh Circuit that, under controlling Illinois law, the failure of a trust through lack of beneficiaries would cause a resulting trust in favor of the settlor to arise.

${ }_{3}$ The phrase "possibility of reverter" is frequently used to describe the settlor's possibility of regaining the property under circumstances such as in the Spiegel case. However, it is not technically accurate to use the property label "a possibility of reverter" to characterize the settlor's interest. See $x$ Tiffany, The Law of Real Property $\$ 93$ (I920). In reality, upon the failure of beneficiaries, a resulting trust in favor of the settlor arises. It has, however, become accepted phraseology to term this interest"a possibility of reverter"or a "reversionary interest."

${ }_{14}$ The value of the settlor's possibility of reverter in $\mathrm{rg}_{92} \mathrm{O}$, when he created the trust, was $\$ 4,000$. Its value decreased with the birth of successive grandchildren. 
III

A detailed recounting of the judicial mishandling of Section $8 \mathrm{II}(\mathrm{c})$ has been made at length elsewhere ${ }^{15}$ and is not necessary for an appreciation of the implications of the Church and Spiegel decisions. The tortuous history of the section can be sketched by a more general treatment of its main line of development. In two early interpretations, the Supreme Court narrowly restricted the appli-

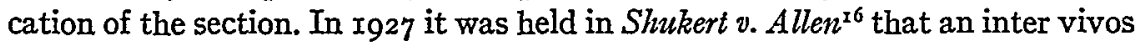
trust providing for the accumulation of income and the distribution of the corpus and accumulated income to the beneficiaries at a time when the settlor probably would be dead did not have to be included in the decedent's gross estate at his death. The Court held that an interest to come into enjoyment after the donor's death need not be included in the donor's gross estate if the donor's transfer of the interest was unaffected by whether he lived or died. In Reinecke v. Northern Trust Co. ${ }^{17}$ the settlor had executed several trusts which provided, in substance, that certain beneficiaries were to receive the income until their deaths, or until five years after the donor's death, whichever event occurred first, whereupon named remaindermen were to receive the corpus. The Supreme Court held that the fact that a gift "was intended to take effect . . . at or after ... death. . .." was not alone sufficient to bring the trust back into the donor's estate. It required, in addition, that there must be a "passing from the possession, enjoyment or control of the donor at his death" before the trust would be included in the decedent's estate pursuant to Section $8 \mathrm{I} \dot{\mathrm{i}}(\mathrm{c})$. The result of the Shukert and Reinecke decisions was that the corpus of a trust which was to be distributed at or after death was not, by virtue of that fact alone, included in the decedent's gross estate, although a literal reading of Section $8 \mathrm{II}$ (c) would suggest an opposite result.

The next significant case interpreting the section was $M a y$ v. Heiner ${ }^{18}$ in I930. In this case, the decedent had executed a trust giving the income to her husband for his life, then to herself for life, and after her death to the children. A trust reserving a life estate in the donor would seem to be one most clearly required to be included in the decedent's gross estate by Section $8 \mathrm{II}$ (c). "It is true that an ingenious mind may devise other means of avoiding an inheritance tax, but the one commonly used is a transfer with a reservation of a life estate."xg "Our prospective decedent who keeps a life estate is anxious to enjoy as if he never gave and to avoid as if he actually gave." ${ }^{\prime 20}$ But, despite the clear applica-

is For a detailed analysis of the case history of Section $8 \mathrm{Ix}$ (c) see Eisenstein, Estate Taxes and the Higher Learning of the Supreme Court, 3 Tax L. Rev. 395 (r948); Paul, Federal Estate and Gift Taxation, $\$ 7.21$ et seq. (I942), I946 Supplement $\$ 7.21$ et seq.

${ }^{{ }^{6}}{ }_{273}$ U.S. 545 (1927). $\quad{ }^{17} 278$ U.S. 339 (I929). $\quad{ }^{18} 28 x$ U.S. 238 (1930).

${ }^{9}$ Matter of Keeney, I94 N.Y. 28r, 287, 87 N.E. 428,429 (I 909 ), aff'd sub nom. Keeney v. New York, 222 U.S. 525 (I9r2).

${ }^{20}$ Eisenstein, Estate Taxes and the Higher Learning of the Supreme Court, 3 Tax L. Rev. 395,448 (r948). 
bility of the section, the Supreme Court refused to hold that a trust with a reserved life estate must be included in the decedent's gross estate.

The rationale of this surprising holding, the affirmation of which by the Supreme Court a year later "came . . . like a bombshell" to Congress, ${ }^{2 \pm}$ was derived from the Reinecke case. The latter case determined that a "passing from the possession, enjoyment or control of the donor" at death was a prerequisite to the inclusion in the decedent's gross estate of the interests transferred. In the May case, Justice McReynolds centered his attention on "passage . . . from the donor," but ignored the phrase "possession, enjoyment or control. . .." He ruled that since "title" passed to the beneficiaries when the trust was created, their interests were fixed at that time and Section $8 \operatorname{Ir}(c)$ did not require the inclusion of the transfers in the gross estate. Clearly, however, "enjoyment" of the trust income did pass to the beneficiaries at the settlor's death and a proper application of the Reinecke rule would have led to a different result in the May case.

The May case, though frequently criticized, was an accepted precedent prior to the decision in Helvering v. Hallock ${ }^{22}$ in 1940 . Although the Hallock case did not involve the settlor's retention of a life estate, but rather concerned the retention of a reverter by the settlor, the rationale of the decision was relevant to transfers involving retained life estates. In the Hallock case, the settlor created an inter vivos trust giving the income to his wife for her life. Upon the death of the wife, the principal and income were to return to the settlor, or, if he were not then living, they were to go to his children. The enjoyment of the children's interests was dependent upon the death of the grantor, and therefore their value was included in the decedent's gross estate. The Court reasoned that if a settlor makes a gift of interests contingent upon his death the transfer of such interests is akin to a testamentary disposition. ${ }^{23}$

The Hallock ruling destroyed the keystone of the May case rationale that complete passage of title before the settlor's death prevents the application of Section 8II(c). The Court determined in the Hallock case that the section required the Court to ascertain realistically when the interests transferred took effect in "possession or enjoyment" rather than to ascertain legalistically when

${ }^{2 x} 74$ Cong. Rec. 7078 (193r).

22309 U.S. I06 (I940).

${ }^{23}$ The Hallock decision overruled Helvering v. St. Louis Union Trust Co., 296 U.S. 39 (I935), and Becker v.St. Iouis Union Trust Co., 296 U.S. 48 (I935). The latter cases held that if the remainder interests are vested at the time of the creation of the trust, subject to divestment in the event the donee predeceases the donor, the gift is technically vested and not contingent on the donee's survivorship. Hence, the Court held there was nothing akin to a testamentary disposition, and thereby made the imposition of the estate tax dependent upon the technical phraseology of the trust instrument. The Court had previously held in Klein v. United States, 283 U.S. 23I (r93r), that if the remainder interests were contingent in form they were subject to the estate tax. In repudiating the St. Louis Union Trust Co. cases, the Court refused to recognize a distinction between gifts with a condition precedent and those with a condition subsequent. If the effect of the trust was that no remainderman could enjoy his gift except by surviving the donor, the Court held that the gift was contingent on the donor's death. 
"title" passed. Mr. Justice Frankfurter colorfully observed that the "unwitty diversities" and "casuistries" of property concepts should not be determinative in taxation questions. The last chapter in the interplay of the life estate and reverter cases is the Church case, where the Court repudiated the May case on the basis of the Hallock decision, and thus created a more consistent body of judicial interpretation of Section $8 \mathrm{II}(\mathrm{c})$.

The undermining of the $M a y$ case as an authoritative precedent continued after the Hallock decision. In Fidelity-Philadelphia Trust Co. v. Rothensies ${ }^{24}$ the Court's holding that certain interests should be included in the decedent's gross estate implied a repudiation of the May case. The donor in the Fidelity case had created an inter vivos trust reserving the income for life. After the donor's death his surviving daughters were to take, and after their death, the daughters' surviving descendants were to take. But if both daughters died without descendants surviving, the corpus was to go to such persons as the settlor might appoint by will. The Court held the entire corpus of the trust was to be included in the decedent's gross estate, because until his death it was uncertain whether the property would ultimately pass by the power of appointment or by the trust instrument. The Court refused to deduct the value of the daughters' life estates before computing the tax, although these interests were not subject to the power of appointment. These interests were contingent, as were those in the $M a y$ case, only in that they followed the donor's life estate. By refusing to deduct the value of these interests, the Court repudiated the May case. ${ }^{25}$

Following the Hallock decision the Tax Court generally had committed itself to a policy of drawing the line between trusts containing remote reverters and those containing less remote reverters. Only the latter type of trusts were included in the gross estates of decedents. ${ }^{26}$ The extension of the Hallock holding in the Spiegel case to remote reverters was foreshadowed by Com'r v. Estate of Field.77 The significant fact in the Field case was the settlor's retention of a remote reverter. The case was like the Church case in that the settlor retained both a life estate and a possibility of reverter. By requiring the trust to be included in the decedent's gross estate as a result of the Hallock holding, the Court's decision indicated that the remoteness of the possibility of reverter was irrelevant. Inasmuch as the Court had not expressly considered the remoteness of the reverter in the Field case, it was not certain even after that case that remoteness was no longer an issue of importance.

${ }^{24} 324$ U.S 108 (1945).

${ }_{25}$ Compare Goldstone v. United States, 325 U.S. 687, 693 n. 3 (I945). The Fidelity case was granted certiorari only to consider the valuation point; hence, the Court did not directly consider whether May v. Heiner should be overruled.

${ }^{26}$ See Paul, Federal Estate and Gift Taxation (Supp., I946), § 7.23, for a full discussion of the Tax Court's application of Helvering v. Hallock.

${ }^{27} 324$ U.S. 108 (I945). The settlor created an inter vivos trust reserving the income for life. The trust was to endure for the lives of two of the settlor's nieces. If both nieces died before the settlor, the corpus was to be paid over to him rather than to beneficiaries named in the trust. 
The Spiegel case explicitly stated that remoteness of a reverter is irrelevant..$^{28}$ And, in addition, the Spiegel decision resolved another problem raised by the Hallock case. It was uncertain after the Hallock decision whether its holding applied to trusts containing reversions not expressly retained but arising by operation of law.29 The Spiegel case held that trusts with reverters arising by operation of law were to be included in the decedent's gross estate.

The Treasury Regulations following the Hallock and Fidelity cases $^{30}$ summed up the status of Section $8 \mathrm{II}$ (c) by stating that an inter vivos transfer would be included in the decedent's gross estate if (I) the possession or enjoyment of the transferred interest could be obtained only by beneficiaries who must survive the decedent and (2) the decedent or his estate possessed some right or interest in the property other than a life estate. The Bureau has proposed to bring the Regulations into conformity with the Church decision by striking from the second condition the clause "other than a life estate." ${ }^{1}$ No change in the Regulations is proposed as a result of the Spiegel decision.

\section{IV}

The conflicting and lengthy Supreme Court opinions in the Church and Spiegel cases, and the excitement they engendered, especially the vigorous reaction of the tax bar, obscure the relatively limited scope of the cases. The application of the Church holding is limited to trusts executed before I93I. In that year the possibilities created by the May case for wholesale estate tax evasion were hastily checked by Congress. After the Supreme Court affirmed the May case in three per curiam decisions, ${ }^{32}$ a Joint Resolution ${ }^{33}$ was passed requiring trusts reserving life estates to be included in the donor's gross estate. The Resolution was later judicially construed to have only a prospective application; ${ }^{34}$ thus, trusts created before I93I reserving life estates were protected from the estate tax by the rule in the May case. By overruling the May case, the Church case requires these early trusts to be included in the decedent's estate. These early trusts can be viewed as falling into two different groups-those trusts created by settlors now deceased whose estate tax liability under Section $8 \mathrm{Ix}$ (c) has not yet been finally determined, and those trusts created by settlors who have not

${ }^{28}$ If a gift is taxed because it is contingent upon the donor's death, the remoteness of the likelihood that the gift will revert to the donor has no logical significance. The gift is equally contingent whether the reverter is or is not remote.

${ }^{29} \mathrm{~A}$ reverter arising by operation of law is one created by law when the settlor has failed to dispose of his complete interest in the trust property.

${ }^{30}$ Reg. I05, § 81.I7 (I942), as amended by T.D. 55I2 (I946).

${ }^{3 x}$ Proposed Amendments to $\S 8 \mathrm{r} .17,8 \mathrm{r}$.I8 of Estate Tax Regulations, Bureau of Internal Revenue, Treasury Department (April 15, I949).

${ }_{32}$ Burnet v. Northern Trust Company, 283 U.S. 782 (I93I); Morsman v. Burnet, 283 U.S. 783 (I93I); McCormick v. Burnet, 283 U.S. 784 (r93r).

3346 Stat. I5I6-I7 (I93I), 26 U.S.C.A. § 8II(c) (I947).

34 Fassett v. Welch, 303 U.S. 303 ( 1938$)$. 
yet died. The former group are protected from tax consequences under Section 8II(c) by the proposed amendments to the Treasury Regulations limiting the application of the Church decision to the estates of settlors who have died or will die after January 17 , I949, the date of the Church decision. ${ }^{35}$ Because relatively few settlors are still living who created trusts reserving life estates before I93I, the limited application of the Church case is apparent.

The Spiegel decision added little to past interpretations of Section $8 \operatorname{Ir}(\mathrm{c})$ and raised few problems for the future. The sophisticated among the tax bar were forewarned of the eventuality of the Spiegel result even before the Hallock case. The decision in Klein v. United States ${ }^{36}$ in I93 I made apparent that trusts with possibilities of reverter expressly retained by settlors might be brought back into their gross estate at death. The Hallock case emphasized the dangers of such retention. Probably few trust instruments containing possibilities of reverter were executed by cautious draftsmen after these decisions. Also, the Fidelity case signaled the tax bar that trusts with remote reverters arising by operation of law would likely also be encompassed by the Hallock ruling. ${ }^{37}$

The heavy tax consequences of the Spiegel decision will be felt by one small group of estates. Although past decisions warned of the impending Spiegel holding, the Tax Court did not require trusts with remote reverters arising by operation of law to be included in decedents' gross estates before the Spiegel decision. The Spiegel decision, then, is limited to the estates of settlors still living or to the estates of settlors who have died but whose estate tax consequences have not been determined. But settlors who are still living can probably avoid the Spiegel result by conveying any possible interest they may have retained to a charity or to the United States Government, and future settlors can accomplish a like result by including a similar clause in the trust instrument. Thus, the remaining group of estates presently vulnerable to the drastic tax result of the Spiegel decision are those few estates now in the process of having their estate tax liability determined.

Certain minor practical problems are left in the wake of the Spiegel decision. As pointed out above, settlors of Spiegel-type trusts who are still living may attempt to avoid the inclusion of the trusts in their gross estates at death by conveying to a charity any interest they retain. The Commissioner might argue that conveyances by settlors of remote possibilities of reverter were "in contemplation of death, ${ }^{38}$ since the motive was avoidance of the estate tax. However,

35 Proposed Amendments to $\S 8$ r.r7, 8I.I8 of Estate Tax Regulations, Bureau of Internal Revenue, Treasury Department (April I5, 1949). The Proposed Regulations also made changes in the examples as a result of the Church decision. Example 6 was struck out in its entirety and a new example inserted in lieu of it.

${ }^{36} 283$ U.S. $23^{\text {I }}$ (x93x). See note 23 supra.

37 Paul, Federal Estate and Gift Taxation (Supp., I946), $\$ 7.21$ et seq.

${ }^{38}$ United States v. Wells, 283 U.S. 102, II7 (I93I): A gift is in contemplation of death if the motive which induces it is of the sort which leads to testamentary disposition. 
in view of Allen v. Trust Co. of Georgia, ${ }^{39}$ such an argument would probably not be upheld. In 1935, the Supreme Court held that trusts reserving to the settlor the power to amend with the consent of the trustees and beneficiaries must be included in the settlor's gross estate at death..$^{4}$ The settlor in the Allen case, who was a lawyer, immediately thereafter renounced his power to amend a trust he had executed in I924. The Court held that the renunciation was not in contemplation of death and the trust did not therefore need to be included in the decedent's gross estate. The rationale of the decision was that if the release by the settlor was to carry out his original trust plan, it would not be considered in contemplation of death. If the Court follows the Allen decision in the analogous situation of a conveyance by a settlor of any possible interest he may retain, the trust would not be included in the decedent's gross estate at death..$^{x}$

Settlors who have created trusts such as that in the Church case will not be as willing to convey away their life estates simply to avoid the result of that decision, since it is likely that these trusts were created by settlors with the intention of depending upon the income from them during life.

A possible means of circumventing the Spiegel decision is suggested by a recent Minnesota statute..$^{2}$ The statute provides that in all trusts where a reversionary interest in the settlor would arise by operation of law, a resulting trust in favor of the state shall henceforth be deemed to arise. The statute applies both to trusts created in the past and to those to be created in the future. By destroying a settlor's possibility of reverter, the Minnesota statute makes ineffectual the result of the Spiegel decision on Minnesota residents inasmuch as the federal courts follow state property law. 43

\section{$\mathrm{V}$}

The minor practical problems presented by the Church and Spiegel decisions do not explain the unusual interest they have aroused. Perhaps a good deal of the interest may be explained by the departure from precedent in the Church case. The overruling of a statutory interpretation of so many years' standing was disconcerting, although, as pointed out, the May case had been universally

${ }^{39} 326$ U.S. I63 (I946).

$4^{\circ}$ Helvering v. City Bank Farmers Trust Co., 296 U.S. 85 (I935).

4r A possible means of avoiding the "contemplation of death" problem would be to sell the possibility of reverter for its exact actuarial value. It has been contended that the settlor's possibility of reverter cannot be conveyed because of the common-law rule that a possibility of reverter was not assignable. Schuyler, Property Law Still Has Tax Consequences, 29 Chicago Bar Record 248, 29 Chicago Bar Record 297, 308 (1948). However, strict adherence to the common-law property rule does not seem appropriate in these cases since the settlor's interests are resulting trusts rather than true "possibilities of reverter."

42 Minn. L. 1949, c. 20 (approved March 26, I949).

43 Another possibility for legislative correction of the Spiegel result would be a congressional act providing that only the actuarial value of the possibility of reverter should be included in the decedent's gross estate if the reverter is remote and arises by operation of law. A bill so providing was introduced in the 8oth Congress. H. Res. 6712, 8202 (May 26, r948). It died in the House when Congress adjourned for the summer. 
condemned as an erroneous interpretation and the Hallock case had destroyed its basic premise. ${ }^{44}$ The overruling of the May case was especially surprising because it was uninvited: the contention that it should be discarded had not been raised by the parties in the lower courts and was not argued by counsel until the Supreme Court asked for argument on rehearing.

A more personal source of annoyance to the practitioner was the upsetting effect of the Spiegel decision on trust plans already created. Experienced members of the bar who had carefully drafted trust instruments for wealthy clients in the I920's or earlier could not have been expected to foresee the tortured history of Section $8 \mathrm{rr}(\mathrm{c})$ culminating in the Spiegel decision. Yet the enormous added taxes levied on particular estates as a result of this understandable failure to foresee are none the less discomfiting. The beneficiaries of the Spiegel trust were deprived of one-half the corpus by the $\$ 450,000$ increased tax resulting from the settlor's inadvertent retention of a negligible interest. The fact that relatively few estates may be affected is small consolation to the clients and law firms who are hit.

Although the attorneys who had drafted these estate plans were forewarned of the probability of the Spiegel decision by the Hallock, Fidelity, and Field cases, as a practical matter there was generally little they could do to avoid the impending effect on their clients. Lawyers were reluctant even after these decisions to suggest revision of carefully planned trust arrangements merely on the basis of conjecture, especially since the reverter interests usually were of minute value. In addition, the attorneys' doubts were quieted by the Treasury Regulations following the Fidelity decision. The destruction of this feeling of security by the Church and Spiegel cases was not accepted with equanimity.

An aspect of the Spiegel decision which aroused speculation was the Court's holding that all of the interests created by the inter vivos trust should be brought back into the decedent's gross estate. The entire corpus at the settlor's death, amounting to $\$ 1,140,000$, rather than the corpus minus the value of a part of the children's interest, was brought back into the gross estate, although this issue was not argued by counsel and was not discussed in any of the opinions. The inclusion of these interests in the Spiegel estate appears to be inconsistent, from one point of view, with the procedure suggested by the Hallock case. ${ }^{45}$ In the Hallock trust, the donor gave his wife an immediate life estate. $4^{6}$

44 Overruling former statutory interpretations is a violation of an important canon of stare decisis. Once the Court has determined the meaning of a statute, subsequent changes in the determination of that meaning are, in effect, legislation. However, the Supreme Court has previously violated this division of duties between the legislative and judicial bodies. Com'r v. Church is another example of such judicial misconduct. See Levi, An Introduction to Legal Reasoning, I5 Univ. Chi. L. Rev. 5or, 5 I9 (1948), for a complete discussion of statutory construction and the judicial process.

45 Everett, Valuation of a "Possibility of Reverter" under the Hallock Case, 18 Taxes 6II (1940), explains the valuation procedure of the Hallock case.

${ }^{6}$ Upon the wife's death, the corpus was to go to the donor's children, or, if he were still living, it was to revert to him. The possibility of reverter caused the trust to be taxed under Section $8 \mathrm{Ir}(\mathrm{c})$. 
Since the donor's death had no effect upon the enjoyment of this interest, the value of the wife's life estate was not brought back into the decedent's gross estate. ${ }^{47}$ The Spiegel trust differs from the Hallock trust in that the beneficiaries' income interests in the Spiegel trust were measured by the settlor's life. However, these beneficiaries were also the contingent remaindermen who received the corpus upon surviving the settlor. The effect of the trust was therefore to give Spiegel's three children, at the very least, income interests for their lives. Either the children would predecease the donor, in which case they would have had life interests, or they would survive the donor, in which case they would then have received, in addition, the entire corpus. In either event, interests equivalent to life estates were conferred upon them by the trust instrument and the donor's death could have no effect on these interests..$^{8}$

Much of the interest shown in the Spiegel decision probably resulted from a belief that its scope might be extended beyond the particular facts at issue in the case. Comments on the Spiegel case ${ }^{49}$ have suggested that the decision holds that any trust in which the settlor retains a possibility of reverter is now subject to the estate tax under Section 8II(c), regardless of whether the contingency attached to the remainders is associated with the donor's death..$^{\circ}$ Certain dicta in Justice Black's majority opinions in the Church and Spiegel cases justify this broad application. ${ }^{51}$ The actual holding of the case, however, is that an interest transferred by trust must be included in the decedent's gross estate if the settlor's retention of a possibility of reverter is such that the transferred interest

47 The Supreme Court opinion in the Hallock case did not determine the measure of the tax but decided only that the estate tax should be imposed. Upon a return of the case to the Board of Tax Appeals, the Commissioner made a recomputation of the tax due, holding that the actuarial value of the wife's life estate should be deducted from the corpus of the trust before the tax was computed.

$4^{8}$ See Fidelity-Philadelphia Trust Co. v. Rothensies, 324 U.S. IO8, III (I945), where the Court stated, "The taxable gross estate . . . must include those property interests the ultimate possession or enjoyment of whch is held in suspense until the moment of the grantor's death or thereafter."

${ }^{49}$ See Conway, I.R.C. $\$ 8$ II (c)-The Church and Spiegel Interpretation, 34 Corn. L. Q. 376, 390 (1949); Foosaner, New Estate Planning Hazard, 88 Trusts \& Estates, 108, rog (1949); Schrenk and Wellman, The Church and Spiegel Cases, 47 Mich. I. Rev. 655, 673 (I949).

$5^{\circ}$ Carefully drafted trust instruments generally provide for the contingency of the death of named beneficiaries by listing several alternate takers. It is always theoretically possible that all the takers might die before the time their interests come into enjoyment. Because of this theoretical likelihood, the settlor or his estate in nearly every trust retains a possibility of reverter.

${ }^{5 x}$ Estate of Spiegel v. Com'r, 335 U.S. 70I, 705 (I949). In the Church case, Justice Black said, "[A]n estate tax cannot be avoided by any trust transfer except by a bona fide transfer in which the settlor, absolutely, unequivocally, irrevocably, and without possible reservations, parts with all of his title and all of his possession and all of his enjoyment of the transferred property. After such a transfer has been made, the settlor must be left with no present legal title in the property, no possible reversionary interest in that title, and no right to possess or to enjoy the property then or thereafter." Com'r v. Estate of Church, 335 U.S. 632, 645 (I949). 
is in any way contingent upon the settlor's death. The contingency of the transfer upon the donor's death rather than the retention of a reversionary interest appears to be the decisive factor.

At the root of the bar's concern over the Spiegel decision might have been the possibility that the Treasury Regulations would be changed to conform to this dicta rather than to the more limited holding of the case. The Bureau's announcement that no changes in the Regulations would be made as a result of the Spiegel case relieved, at least for the time being, the uneasiness of the bar that all trusts containing reverters would henceforth be included in decedents' gross estates. ${ }^{52}$ The first condition of taxability laid down in the Regulations following the Hallock and Fidelity cases is still in effect-namely, that it must be necessary for the donees to survive the donor in order to take. ${ }^{53} \mathrm{Had}$ the Regulations followed the dicta, this condition would have been discarded. The Bureau's reluctance to incorporate Justice Black's sweeping language into the Regulations may well have been influenced by the excitement of the bar, and the probability of legislative nullification had it done so.

Little criticism can properly be directed at the Court's statutory interpretation in the Church case, despite its departure from precedent, or at the reasonable extension of the Hallock doctrine made in the Spiegel case. Underlying the manifestations of interest in the two cases is, perhaps, in addition to an appreciation of their significance as statutory interpretations, a concern over the greater impact of the estate tax resulting from judicial decision. Although at present the estate tax touches "only about I\% of those who die in adult age," said that the effect of the tax upon large estates "is so heavy that it amounts to a confiscatory capital levy." 55

As a source of revenue to the Government the estate tax is negligible, but it is of major importance as an aspect of a social policy designed to limit large accumulations of wealth..$^{6}$ The development of this social policy is dramatically illustrated by two cases-the early case of May v. Heiner, where the most obvious device for circumventing an estate tax was excluded from the terms of Section $8 \mathrm{Ir}(\mathrm{c})$, and the recent case of Estate of Spiegel v. Com'r where a trust trans-

52 Proposed Amendments to $\$ 8$ I.I7, 8I.I8 of Estate Tax Regulations, Bureau of Internal Revenue, Treasury Department (April I5 $_{5}$ 1949).

53 Reg. 105, § 8I.I7 (1942), as amended by T.D. $55^{12}$ (I946).

54 Paul, Taxation for Prosperity 308 (I947), as quoted in Eisenstein, Estate Taxes and the Higher Learning of the Supreme Court, 3 Tax L. Rev. 395 (I948). (I940).

55 Lowndes, Tax Avoidance and the Federal Estate Tax, 7 Law \& Contemp. Prob. 309, 328

${ }^{56}$ "It [federal estate tax] is aimed directly at the destruction of large accumulations of property. Taken in conjunction with current federal spending policies and the federal income and gift taxes, the federal estate tax is part of a deliberate plan to redistribute both the capital and income of the nation." Ibid., at 328 . 
fer which could not in any sense be considered as an attempt to circumvent the estate tax was included within the terms of the section. Opponents of this social policy may well be concerned over the change in judicial attitude from the days of May v. Heiner, when a technical property doctrine was employed to frustrate Section 8II(c), to the days of Estate of Spiegel v. Com'r, when a technical property doctrine was employed to give the section its full scope. 